\title{
Research on the Synergistic Effect of Environmental Protection Investment and Technological Innovation on Corporate Performance
}

\author{
Caimei Lu Haiyan Wang* Jinbo Li \\ School of Economics and Management, Shanxi University, Taiyuan 030006, China \\ * E-mail of the corresponding author: 823014004@qq.com
}

The research is financed by the National Natural Science Foundation of China. No. 71874103 and Shanxi Abstract

Based on the theory of corporate social responsibility, stakeholder theory and resource-based theory, using the panel data of China's listed companies in heavily polluting industries from 2013 to 2017, the paper reveals the complex relationship between environmental protection investment, technological innovation and corporate performance from both short-term and long-term perspectives, especially the synergistic effect of environmental protection investment and technological innovation on corporate performance. The results show that: (1) with the passage of time, the impact of environmental protection investment on corporate performance changed from negative to positive; (2) corporate technology innovation has a positive impact on corporate performance, but the hysteresis exists in the impact; and (3) the impact of environmental protection investment and technological innovation on short-term and long-term performance of enterprises forms a synergistic effect of "1+1>2". Therefore, enterprises should establish the strategy of integration of environmental protection and technological innovation. While government departments strengthen the supervision of environmental violations, they should properly increase the intensity of environmental protection and R\&D subsidies. The public should support the development of green enterprises with practical actions.

Keywords: environmental protection investment, technological innovation, corporate performance, synergistic effects

DOI: $10.7176 / \mathrm{EJBM} / 12-11-01$

Publication date: April $30^{\text {th }} 2020$

\section{Introduction}

With the continuous progress of industrialization and urbanization, environmental pollution and other problems have seriously affected people's normal life, work and health, and also caused immeasurable losses to the country's economy. It can be said that the contradiction between environmental problems, sustainable economic development and people's needs for a better life has become irreconcilable. It is testing the governance level of the party and the country how to solve these contradictions. Since the 18th national congress of the communist party of China (CPC), the central government has taken the construction of ecological civilization to a new height, and integrated it into the whole process of economic, political, cultural and social development. In order to promote the transformation and upgrading of industrial structure and achieve high-quality economic development, China began to implement the innovation-driven development strategy in 2012. The country has strengthened the guiding role of the market in allocating innovative resources, constantly improved the research and development support for technological innovation, and promoted enterprises to become the real main body of investment in technological innovation and transformation of achievements.

Under the above institutional background and practical background, more and more enterprises have increased the practice of environmental protection investment after realizing the importance of environmental protection. At the same time, in order to obtain and maintain differentiated competitive advantages, enterprises also begin to pay attention to the improvement of technological innovation ability. Technology innovation can make the corporate to better optimize allocation of production factors, improve the utilization efficiency of environment resources (Wang \& Xie 2014), while environmental investment is an important means for enterprises to fulfill environmental responsibility and improve environmental performance. It can significantly improve the social image of enterprises, win the affirmation and support of stakeholders (Lopez-Gamero et al. 2010). Then, what is the relationship between environmental protection investment, technological innovation and corporate performance? How do they work together to improve corporate performance? Porter hypothesis thinks environmental protection investment can promote corporate technology innovation and help them establish green, innovative corporate social image, and improve corporate productivity and market competitiveness, and have a positive impact on corporate performance from the corporate dynamic development perspective (Broberg et al. 2013). To answer these questions, the article is based on Porter hypothesis but not limited to this hypothesis, and takes corporate social responsibility theory, stakeholder theory and resource-based theory as the theoretical basis. 
We manually collected the environmental protection investment data of China's listed companies in heavy pollution industry from 2013 to 2017, and revealed the complex relationship between corporate environmental investment, technological innovation and corporate performance from the short-term and long-term perspective, especially the synergistic effect of corporate environmental protection investment and technological innovation on corporate performance.

There are two possible contributions to this article. First, from the perspective of research, this paper reveals the complex relationship between corporate environmental protection investment, technological innovation and corporate performance from both short-term and long-term perspectives. However, previous researches only explore relevant issues from a single perspective and tend to draw one-sided conclusions. Therefore, this paper makes up for the deficiency of existing literature, enriches the research perspective of relevant issues, and helps to further understand the mechanism and essence of the impact of environmental protection investment and technological innovation on corporate performance. Second, in terms of research content, existing researches mainly focus on the simple correlation between environmental protection investment, technological innovation and corporate performance. Few scholars have tested the synergistic effect of environmental protection investment and technological innovation on corporate performance through empirical research. This paper uses the data of heavy pollution industry in China to find the empirical evidence of this problem and provides a new idea for enterprises to make full use of environmental protection resources and technological innovation resources to improve corporate performance.

\section{Literature Review and Research Hypothesis}

\subsection{Literature Review}

The theory of environmental accounting and technological innovation is a hot topic at home and abroad, and has achieved a lot of research results. From the micro level, the relationship between environmental protection investment, technological innovation and corporate performance is mainly studied from the following aspects:

(1) The impact of environmental protection investment on corporate performance

The traditional view is that corporate environmental investment practices can squeeze limited corporate resources and increase corporate costs. Walley \& Whitehead (1994) pointed out that it is not easy for enterprises to achieve green development. They think corporate environmental compliance investment and environmental technology research and development investment can occupy other aspects of the company's cash flow, resulting in higher opportunity costs, and the company's product benefits are not enough to make up for sustainable environmental protection investment. Therefore, the corporate environmental investment reduces the corporate performance, which is contrary to the principle of maximizing corporate economic benefits. Sarkis et al. (2010) 's research is similar to the above viewpoint, holding that enterprises may consume a large amount of funds when they carry out environmental protection practices such as the construction of environmental protection facilities, the introduction of advanced environmental protection technologies and the purchase of environmental protection equipment, but these inputs cannot bring direct economic income to the company. Broberg et al. (2013) used the Swedish manufacturing corporate sample to test the static and dynamic effects of corporate environmental protection investment on corporate productivity. They estimated the stochastic production frontier model function showed that environmental protection investment would lead to the loss of corporate production efficiency.

The revision school represented by Porter believes that enterprises' investment in environmental protection can not only help enterprises establish the social image of green enterprises, but also stimulate enterprises to make up for the production cost caused by environmental protection investment by improving innovation ability, and the economic value created by enterprises is much higher than their investment in environmental protection (Russo \& Fouts 1997). Sharfman \& Fernando (2008) and Rob \& Jan (2009) found that environmental protection investment practices have an impact on the ability of enterprises to raise direct financing (issuing bonds) and indirect financing (bank loans), because most of the financial institutions or investors will take corporate's environmental protection investment behavior as a means of reducing the risk of environment, thus more preference for the corporate to provide financing, which makes the corporate owned good environmental performance easier to obtain financing and achieve rapid development. Of course, some scholars find that there is not a linear relationship between environmental protection investment and corporate performance, but a u-shaped curve relationship (Zhao 2015). It can be seen that the relationship between corporate environmental protection investment and corporate performance is complex, which not only varies with different internal characteristics of enterprises, but also produces opposite results due to different external environments of enterprises (Liu \& Duan 2013).

(2) The impact of technological innovation on corporate performance

Technological innovation has a profound impact on the allocation and conversion efficiency of input and output of industrial enterprises, and constantly promote social industrial upgrade and economic structure transformation. Tsai \& Wang (2010) estimated the results of Cobb-Douglas function, indicating that the productivity output elasticity of R\&D investment to enterprises is about 0.18 , and high-tech corporate $R \& D$ output elasticity is 
significantly higher than traditional enterprises. Liang Laixin and Zhang Huanfeng (2005) take China's high-tech enterprises as the research object, the empirical study finds that the R\&D of high-tech enterprises in our country has a significant influence to the profit ability and development ability, and the hysteresis exists in the influence. Zhang Botao (2008) found that technological innovation (patent) and corporate main business profit and income are characterized by "inverted U" relationship. Research shows that technological innovation information (R\&D input and innovation output information) not only has value correlation (Wu et al. 2017), but also has significant positive correlation with stock price and stock volatility (Chan et al. 2001). Luo Ting et al. (2009) found that corporate R\&D investment was positively correlated with annual profit on the whole, and not correlated with stock price changes during the same period, but the cross-period effect exist in the relationship. The inter-temporal valuation effect indicates that investors do not fully realize the value of R\&D in the year of investment, and will make adjustments for such underestimation in the following year.

(3) The synergistic impact of environmental protection investment and technological innovation on corporate performance

Nowadays, no scholars have directly explored the synergistic effect of environmental protection investment and technological innovation on corporate performance, but indirect evidence of this problem can be found in existing literatures. Based on corporate resource theory, Chen et al. (2015) used high-tech enterprises in China as the research sample to conduct empirical study. The results show that innovation resources investment has significant positive effects on corporate performance, but it is not enough to rely solely on innovative resources to improve corporate performance, also requires the coordination of key resources such as manpower, market and manufacturing. Zhu et al. (2014) also took Chinese high-tech enterprises as research samples to explore the complex relationship between CSR commitment, technological innovation input and corporate performance, the empirical results show that corporate social responsibility as well as the technical innovation investment can have a positive impact on corporate performance, further analysis shows that CSR commitment and technological innovation investment have a synergistic effect on the short-term and long-term performance of enterprises. Lioui \& Sharma (2012) believe that enterprises will develop or adopt new technologies to cope with the environmental pressure brought by environmental regulations and make the production process more effective. Therefore, R\&D investment can be seen as a potential variable in which corporate environmental responsibility indirectly affects corporate performance. Empirical studies have found that although the impact of corporate environmental responsibility on corporate performance is negative, the interaction between corporate environmental responsibility and R\&D investment has a positive impact on corporate performance. Environmental protection investment is an important means for enterprises to undertake environmental responsibility, and environmental responsibility is an indispensable factor for the evaluation of corporate social responsibility. Meanwhile, corporate environmental resources are complementary resources of innovation resources, so it can be inferred that together with innovative resources and environmental protection investment can have a positive impact on corporate performance.

In conclusion, we can find that scholars' researches on the relationship between corporate environmental protection investment, technological innovation and corporate performance focus on simple correlation, while few scholars further explore the interaction and synergy between corporate environmental protection investment and technological innovation on corporate performance. Especially in China, due to the lack of transparency and standardization of corporate information disclosure, there are few literatures exploring relevant issues through empirical research methods. In addition, there are some contradictory theoretical explanations and empirical studies on the research results at home and abroad. In view of this, we firstly explores the impact of environmental protection investment and technological innovation on corporate performance and the hysteresis of the effect. On this basis, we further test the synergistic effect of environmental protection investment and technological innovation on corporate performance. Therefore, the existing theories are supplemented to provide theoretical basis and suggestions for the decision-making of enterprises and government departments.

\subsection{Theoretical Analysis and Research Hypothesis}

(1) Environmental protection investment and corporate performance

Based on the theoretical analysis and empirical research of existing literatures, the relationship between environmental protection investment and economic benefits can be divided into the blocking stage in the early stage and the promoting stage in the later stage. On the one hand, the renewal and engineering construction of environmental protection equipment of enterprises are mostly in the early stage of corporate operation and the amount of investment is large. The effectiveness of scale has not been effectively exerted, the environmental and economic benefits brought about by the company cannot be seen in the short term, and enterprises in environmental protection efforts to get the recognition and support of stakeholders also need time, so environmental protection investment are more likely to focus on the negative effect on the corporate performance in the short term. However, on the other hand, environmental risk has become a major risk that cannot be ignored in the operation process of enterprises (Sharfman \& Fernando 2008). Even if there is a slight carelessness, the environmental protection 
department will suspend business for rectification, impose fines and other penalties due to environmental problems. enterprises invest in ecological environmental protection in order to avoid environmental risks, which will consume a lot of capital and resources in a short time, but the good reputation and support from stakeholders will help enterprises improve their market competitiveness in the future (Russo \& Fouts 1997). According to the theory of corporate social responsibility and the theory of stakeholders, the active implementation of environmental responsibility by enterprises can establish a good social image in the minds of stakeholders, which will help enterprises to maintain good relations with stakeholders, and thus enable enterprises to obtain more public capital including corporate production and operation qualification, natural environment resource utilization and legal protection in company operation. At the same time, environmental protection investment as a capital investment of enterprises, in addition to the real benefits of improving the production environment, reducing the discharge of sewage taxes and fees, and the secondary utilization of waste materials, also possibly improve the production efficiency of enterprises due to the transformation of production methods, equipment renewal and research and development of new products, and promote the cultivation of new performance growth points. It can be seen that environmental protection investment helps enterprises to realize the second transformation and upgrading of production mode and value structure. Based on the above analysis, the following hypothesis is proposed:

Hypothesis 1. Corporate environmental protection investment is negatively correlated with corporate short-term (within one year) performance, and positively correlated with corporate long-term (over one year) performance. (2) Technological innovation and corporate performance

Schumpeter who proposed the theory of modern technological innovation pointed out that simple "circulation" does not lead to real economic growth in social development, only through "creative destruction", that is, technological R\&D and innovation, can enterprises better optimize the allocation of production factors, improve the efficiency of operation and production, and obtain sustainable and differentiated competitive advantages. Therefore, once enterprises develop new products to meet customer needs through technological innovation, they can quickly occupy more market shares, greatly reduce product costs through large-scale production, further improve market competitiveness and obtain more excess profits. However, technology R\&D innovation activities are inherently complex, long-term, and uncertain in outcome, the success of R\&D depends on the corporate's comprehensive resource utilization capabilities, and the length of $\mathrm{R} \& \mathrm{D}$ activities is unknown. In addition, a successful technological innovation takes time from launch to market acceptance, and there is a commercialization process. It means that the process of improving corporate performance through technological innovation is long and lagged. Based on this, the following hypothesis is proposed:

Hypothesis 2. Technological innovation has a positive impact on corporate performance, but the hysteresis exist in the impact.

(3) Environmental protection Investment, technological innovation and corporate performance

According to porter's hypothesis, the government's environmental regulations put great pressure on enterprises to protect environment, which will stimulate enterprises to improve product quality and production efficiency through technological innovation, thereby reduce relevant costs and give enterprises a leading competitive advantage in domestic and even international markets (Broberg et al. 2013). The theory of corporate resource foundation also holds that only owning scarce and unimitable resources can make an corporate stand out from the competition, and technological innovation is an important way to obtain such resources. In terms of the actual situation of environmental protection in China, enterprises are facing new opportunities while taking the initiative to take environmental responsibility and avoid environmental risks. In order to prevent and control environmental pollution and other problems, China strongly encourages enterprises to improve their R\&D and innovation capabilities, and promote industrial transformation and upgrading through the transformation of environmental protection and energy saving technologies to increase efficiency and reduce emissions. Government subsidies and tax incentives will undoubtedly reduce the production costs of a large part of the company.

Environmental protection investment and technological innovation for enterprises, therefore, should be merged together the overall strategy, namely, enterprises need to increase the technology innovation investment in environmental management to meet customer demand and maintain the market competition advantages. Correspondingly, in order to obtain the affirmation and support of stakeholders, enterprises need to actively fulfill their environmental responsibilities while increasing their innovation capabilities, and increase investment in environmental protection. That is to say, the impact of corporate environmental protection investment and technological innovation on corporate performance can form a" $1+1>2$ "synergy effect, the existence of which also can make the corporate pay attention to environmental protection investment and increasing the financial input in technology innovation, so that the environmental protection investment, technology innovation and corporate performance can form a virtuous cycle, and lay a solid foundation for the sustainable development of enterprises. Based on the above theoretical analysis, we propose the following hypothesis:

Hypothesis 3. Corporate environmental protection investment and technological innovation regulate each other, which has a synergistic effect on corporate performance. 


\section{Research Design}

\subsection{Sample Selection and Data Sources}

China's heavy pollution industries have many environmental problems, and their environmental regulation pressure is much larger than that of non-heavy pollution industries. The relationship between environmental performance and corporate performance is closer than that of the average corporate (Horváthová 2011). Therefore, for enterprises in heavy polluting industries, it is of great significance for environmental protection and sustainable economic development to make use of the synergistic effect of corporate environmental protection investment and technological innovation to effectively transform the value creation method and promote corporate transformation and upgrading. So taking into account the typicality and representativeness of heavy polluting industries, according to the classification of heavy polluting industries in the 2010 edition of the "Guidelines for Environmental Information Disclosure of Listed Companies" of the Ministry of Environmental Protection, we take related listed companies of 16 industries as research samples empirically such as coal, steel, cement and so on.

We manually collects the company's environmental protection investment data from the sample company's annual report, social responsibility report, environmental report and other raw materials ${ }^{1}$. The original material and other data (corporate performance, technological innovation input and control variable data) are mainly from the Wind financial database. The missing data is supplemented by the CSMAR financial database. In order to obtain effective and reliable data, we screen the data according to the following standards: (1) removing companies with obvious anomalies or missing data; (2) listed companies marked with *ST and ST are excluded in order to reduce the impact of abnormal business operations on the research results; (3) b-share listed companies are excluded. In addition, we also perform Winsorize processing of upper and lower $1 \%$ quantiles on all continuous variables to control the influence of extreme values. After the above processing, this paper finally obtained a total of 1415 observations of 283 above-mentioned heavy pollution industry enterprises from 2013 to 2017. And all data was counted and analyzed using EViews 9.0 software.

\subsection{Variable Definitions}

3.2.1 Explanatory Variables

(1) Environmental Protection Investment (EPI). With reference to Tang et al. (2013) as well as Wang \& Zhang (2016) measurement method of environmental protection investment for our country corporate, combining with the purpose, effect and ecological principles of corporate environmental protection investment, we argue that the scope of corporate environmental protection investment includes: energy conservation and emission reduction expenditure, environmental protection engineering construction investment, environmental technology research and development investment, purchase of environmental protection equipment, ecological environmental protection and governance investment (including greening investment such as afforestation), and endowment fund for environmental protection. In the subsequent empirical research, in order to make each corporate's environmental investment data comparable, we take the ratio of corporate environmental investment to corporate operating income to measure the scale of corporate environmental investment (EPI).

(2) Technological Innovation (R\&D). Existing research on the measurement of technological innovation mainly includes two methods: innovation input (R\&D input or technician input) (Zhang \& Wu.2014; Yang 2015) and innovation output (patent) (Wu \& Tang 2016). As for the heavily polluting industries, there is little difference in the amount of patent output among enterprises. Therefore, we take R\&D intensity to measure the investment in technological innovation of enterprises.

3.2.2 Explained Variables

ROA can comprehensively reflect the enterprises' asset utilization efficiency and profitability, and can better measure corporate performance (Yang 2015; Liu \& Duan 2013). Therefore, we take ROA as the measurement index of corporate performance. We can explore the synergistic effect of environmental protection investment and technological innovation on corporate performance from both short-term and long-term perspectives, and draw on the short-term and long-term division of capital markets (it is generally considered that within one year (including one year) is short-term, more than one year is long). In this paper, we take the current ROA to measure corporate short-term performance, and take ROA lagging one or two phases to measure corporate long-term performance. 3.2.3 Control Variables

The control variables in this paper include corporate Size (Size), financial leverage (Lev), liquidity ratio (Liq), Equity concentration (Equity), property right nature (Pro) and corporate Age (Age). The definition and description of all variables are shown in table 1.

\footnotetext{
${ }^{1}$ We mainly collect environmental protection investment data from the corporate social responsibility report or environmental report. The missing data comes from the increase in the amount of the construction-related borrowings related to environmental protection in the "Inconstruction Project" notes of the company's annual report. The total expenditures of three waste recycling, sewage treatment, environmental treatment, environmental protection design and energy conservation projects are taken as environmental protection capital investment.
} 
Table 1. Variable definitions and explanations

\begin{tabular}{|c|c|c|c|}
\hline Variable types & Variable name & $\begin{array}{l}\text { Variable } \\
\text { code }\end{array}$ & Variable declaration \\
\hline $\begin{array}{l}\text { Explained } \\
\text { variable }\end{array}$ & Corporate performance & ROA & $\begin{array}{l}\text { Return on total assets: net profit/average total } \\
\text { assets }\end{array}$ \\
\hline \multirow{2}{*}{$\begin{array}{l}\text { Explanatory } \\
\text { variables }\end{array}$} & $\begin{array}{c}\text { Environmental protection } \\
\text { investment }\end{array}$ & EPI & $\begin{array}{l}\text { The ratio of enterprises' environmental } \\
\text { protection investment and operating income }\end{array}$ \\
\hline & Technology innovation & $\mathrm{R} \& \mathrm{D}$ & $\begin{array}{l}\text { R\&D intensity: ratio of total } R \& D \text { expenditure } \\
\text { to operating revenue }\end{array}$ \\
\hline \multirow{6}{*}{$\begin{array}{l}\text { Control } \\
\text { variables }\end{array}$} & Corporate scale & Size & The natural logarithm of a firm's total assets \\
\hline & Financial leverage & Lev & Asset-liability ratio: total liabilities/total assets \\
\hline & Current ratio & Liq & Current assets/current liabilities \\
\hline & Ownership concentration & Equity & Shareholding ratio of the largest shareholder \\
\hline & Nature of property & Pro & $\begin{array}{l}\text { Dummy variable, state-owned holding is } 1 \text {, and } \\
\text { non-state-owned holding is } 0\end{array}$ \\
\hline & Age of corporate & Age & $\begin{array}{l}\text { The natural logarithm of the corporate } \\
\text { establishment years }\end{array}$ \\
\hline
\end{tabular}

\subsection{Model Setting}

The main research purpose of this paper is to explore the synergistic effect of corporate environmental protection investment and technological innovation on corporate performance, and mainly using multiple regression analysis method. Drawing on the methods and ideas of Zhu et al. (2014) to test the synergistic effect, we conduct empirical test in the following three steps:

The first step is to take corporate performance (ROA) as the explained variable and corporate environmental protection investment (EPI) as the explanatory variable, and add control variables to build the model (1) to verify the hypothesis 1 , that is, testing the impact of corporate environmental protection investment on corporate shortterm performance and corporate long-term performance. Among them, subscripts $i$ and $t$ represent the company and year respectively, $k$ represents the lag phase, $\alpha_{0}$ represents the intercept of the regression equation, namely the constant term, $\alpha_{1} \sim \alpha_{7}$ represent the regression coefficient of the corresponding variable, and $\varepsilon_{1}$ represents the random error term (similar below).

$$
\begin{aligned}
& R O A_{i, t}=\alpha_{0}+\alpha_{1} E I_{i, t-k}+\alpha_{2} \text { Size }_{i, t}+\alpha_{3} \text { Lev }_{i, t}+\alpha_{4} \text { Liq }_{i, t}+\alpha_{5} \text { Equity }_{i, t} \\
& +\alpha_{6} \operatorname{Pr} o_{i, t}+\alpha_{7} \text { Age }_{i, t}+\varepsilon_{1}
\end{aligned}
$$

The second step is to take ROA as the explained variable and technological innovation (R\&D) as the explanatory variable. By adding the above six control variables to build the model (2), we verify the hypothesis 2 , namely, the influence of technological innovation on corporate performance and the hysteresis of the influence.

$$
\begin{aligned}
& R O A_{i, t}=\beta_{0}+\beta_{1} R \& D_{i, t-k}+\beta_{2} \text { Size }_{i, t}+\beta_{3} \text { Lev }_{i, t}+\beta_{4} \text { Liq }_{i, t}+\beta_{5} \text { Equity }_{i, t} \\
& +\beta_{6} \operatorname{Pr} o_{i, t}+\beta_{7} \text { Age }_{i, t}+\varepsilon_{2}
\end{aligned}
$$

In the third step, we add environmental protection investment (EPI) and R\&D intensity to construction model (3) on the basis of model (1) and model (2), and add the interaction term (EPI*R\&D) of environmental protection investment and R\&D intensity to get model (4). The purpose is to compare with the model (1) and the model (2), to facilitate observe changes in the model interpretation ability, the corporate environmental protection investment coefficient and the corporate technology innovation coefficient as well as whether the influence of the interaction item on the corporate performance is significant. Then we verify the hypothesis 3, namely, corporate environmental protection investment and technological innovation regulate each other and have a synergistic impact on corporate performance.

$$
\begin{aligned}
& R O A_{i, t}=\mu_{0}+\mu_{1} E P I_{i, t-k}+\mu_{2} R \& D_{i, t-k}+\mu_{3} \text { Size }_{i, t}+\mu_{4} \text { Lev }_{i, t}+\mu_{5} \text { Liq }_{i, t} \\
& +\mu_{6} \text { Equity }_{i, t}+\mu_{7} \operatorname{Pr} o_{i, t}+\mu_{8} \text { Age }_{i, t}+\varepsilon_{3} \\
& R O A_{i, t}=\gamma_{0}+\gamma_{1} E P I_{i, t-k}+\gamma_{2} R \& D_{i, t-k}+\gamma_{3} E P I_{i, t-k} * R \& D_{i, t-k}+\gamma_{4} \text { Size }_{i, t} \\
& +\gamma_{5} \text { Lev }_{i, t}+\gamma_{6} \text { Liq }_{i, t}+\gamma_{7} \text { Equity }_{i, t}+\gamma_{8} \operatorname{Pr} o_{i, t}+\gamma_{9} \text { Age }_{i, t}+\varepsilon_{4}
\end{aligned}
$$

\section{Empirical Analysis}

\subsection{Descriptive Statistics of Samples}

Table 2 reports the descriptive statistical results of the research samples in this paper. It can be seen that the average return on total assets of enterprises in China's heavy pollution industries has reached $8.39 \%$, which is close to the 
median $8.30 \%$ of the return on total assets. It shows that the overall profitability of sample enterprises is not much different. The average ratio of environmental protection investment to operating income of the sample enterprises is 0.0097 , and the median is 0.0043 . The median value is much lower than the average value. It indicates that the scale of environmental protection investment of most enterprises in China's heavy pollution industry is lower than the average level, and reflects the current situation that relevant enterprises are not strong enough in environmental protection awareness and investment intensity. In addition, the percentage of R\&D investment in operating revenue, namely, the average of R\&D intensity is $3.16 \%$, and the median is $2.95 \%$, which indicates that the R\&D intensity of most enterprises is above the basic survival line (2\%), but there is still a big gap in the level of input (5\%) that can make it competitive. And the standard deviation (3.55\%) was higher than the mean and median, the maximum and minimum are $76.35 \%, 0$, respectively. It indicates that there are obvious individual differences in the technological innovation investment of enterprises.

Table 2. Descriptive statistics of variables

\begin{tabular}{|c|c|c|c|c|c|c|}
\hline Variable & Sample size & Mean & Median & $\begin{array}{c}\text { Standard } \\
\text { deviation }\end{array}$ & $\begin{array}{c}\text { Minimum } \\
\text { value }\end{array}$ & $\begin{array}{c}\text { Maximum } \\
\text { value }\end{array}$ \\
\hline ROA & 1415 & 0.0839 & 0.0830 & 0.0816 & -0.6408 & 0.5377 \\
\hline EPI & 1415 & 0.0097 & 0.0043 & 0.0154 & 0.0000 & 0.2932 \\
\hline R\&D & 1415 & 0.0316 & 0.0295 & 0.0355 & 0.0000 & 0.7635 \\
\hline Size & 1415 & 3.5903 & 3.4561 & 1.3400 & 0.4816 & 8.6599 \\
\hline Lev & 1415 & 0.3789 & 0.3533 & 0.2064 & 0.0302 & 3.2619 \\
\hline Liq & 1415 & 2.6084 & 1.7621 & 2.9063 & 0.0318 & 33.1605 \\
\hline Equity & 1415 & 0.4402 & 0.4736 & 0.2258 & 0.0251 & 0.8976 \\
\hline Pro & 1415 & 0.2993 & 0.0000 & 0.3580 & 0.0000 & 1.0000 \\
\hline Age & 1415 & 2.8462 & 2.8904 & 0.3154 & 1.3863 & 4.0604 \\
\hline
\end{tabular}

\subsection{Variable Correlation Analysis and Multicollinearity Test}

Table 3 shows the correlation coefficients between the main variables and their significance test results. The correlation coefficient between EPI and ROA is $-0.281(\mathrm{P}<0.05)$, which partially verifies the hypothesis 1 , namely, corporate environmental protection investment is negatively correlated with corporate short-term performance. The current R\&D is significantly positively correlated with the current ROA at the level of $10 \%$, and the correlation coefficient reaches 0.207 . It indicates that hypothesis 2 is partially supported, but it is necessary to further verify the hysteresis of the impact of technological innovation on corporate performance. In addition, there is a significant positive correlation between environmental protection investment and R\&D intensity at the level of $10 \%$, the correlation coefficient reaches 0.148 , and showing a strong correlation. It verifies the theoretical analysis in hypothesis 3 , that is, enterprises should not treat environmental strategy and innovation strategy as separate, maintain overall thinking, integrate environmental protection investment and technological innovation into one, and make overall decision-making. That is to say, enterprises should increase their investment in technological innovation while conducting environmental management, actively fulfill their environmental responsibilities while increasing their innovation capabilities, and increase investment in environmental protection.

Table 3. Variable correlation coefficient matrix

\begin{tabular}{|c|c|c|c|c|c|c|c|c|c|}
\hline & ROA & EPI & R\&D & Size & Lev & Liq & Equity & Pro & Age \\
\hline ROA & 1 & & & & & & & & \\
\hline EPI & $-0.281^{* *}$ & 1 & & & & & & & \\
\hline R\&D & $0.207^{*}$ & $0.148^{*}$ & 1 & & & & & & \\
\hline Size & $-0.113^{*}$ & $-0.242^{*}$ & $-0.420^{* *}$ & 1 & & & & & \\
\hline Lev & $-0.415^{* *}$ & -0.162 & $-0.341^{* *}$ & $0.459^{* * *}$ & 1 & & & & \\
\hline Liq & $0.218^{*}$ & 0.079 & $0.251^{*}$ & $-0.434^{* *}$ & $-0.656^{* * *}$ & 1 & & & \\
\hline Equity & 0.061 & -0.078 & -0.265 & 0.072 & 0.044 & -0.066 & 1 & & \\
\hline Pro & $-0.330^{* *}$ & $-0.209^{*}$ & $-0.450^{* * *}$ & $0.435^{* * *}$ & $0.306^{* *}$ & $-0.197^{*}$ & $0.260^{*}$ & 1 & \\
\hline Age & -0.003 & -0.051 & 0.010 & $-0.152^{*}$ & 0.002 & -0.025 & $-0.329 * *$ & 0.055 & 1 \\
\hline
\end{tabular}

Note: $* * *, * *$ and $*$ respectively indicate that they pass the significance test at the levels of $1 \%, 5 \%$ and $10 \%$.

In order to accurately judge the ultiple-colinearity among independent variables, we use the tolerance of the variable (Tolerance) and the variance expansion factor (VIF) for diagnosis. The results of collinearity diagnosis are shown in Table 4 . The tolerance of all independent variables is greater than 0.1 , or the variance expansion factor is between 1.2159 and 3.4431, which is much less than 10. It indicates that the independent variables do not exist a multicollinearity problem and multiple regression analysis can be performed further. 
Table 4. Collinearity diagnosis results

\begin{tabular}{|c|c|c|}
\hline Variable & Tolerance & VIF \\
\hline EPI & 0.8224 & 1.2159 \\
\hline R\&D & 0.6216 & 1.6087 \\
\hline Size & 0.3662 & 2.7305 \\
\hline Lev & 0.2904 & 3.4431 \\
\hline Liq & 0.4979 & 2.0083 \\
\hline Equity & 0.5332 & 1.8755 \\
\hline Pro & 0.6301 & 1.5871 \\
\hline Age & 0.4238 & 2.3594 \\
\hline
\end{tabular}

\subsection{Analysis of Regression Results}

4.3.1 Test the Relationship between Environmental Protection Investment and Corporate Performance

Table 5 reports the regression results of the impact of enterprises' environmental protection investment on the short-term (within one year) and long-term (over one year) performance. The regression results of model (1a) show that the impact of enterprises' environmental protection investment on the current return on total assets is negative, and the regression coefficient is $-0.3408(\mathrm{P}<0.1)$. It means that, in the short term, the company's total asset return rate will decrease by $34.08 \%$ for every $1 \%$ increase in environmental investment if the existing conditions remain unchanged. It indicates that the investment in environmental protection of enterprises will increase the cost, reduce the operating profit and have an adverse impact on corporate performance in the short term. In fact, it also supports the traditional school's view that enterprises' investment in environmental protection is regarded as an additional burden on enterprises. Model (1b) and model (1c) respectively examine the impact of environmental protection investment on the return on total assets lagging one and two phases. The results show that the impact is not significant that corporate environmental protection investment on the one-period lag return on total assets, but the regression coefficient of corporate environmental protection investment has changed from negative to positive comparing with model (1a). However, the enterprises' environmental protection investment is positively correlated with the two-periods lag return on total assets at the level of $10 \%$, and the correlation coefficient of 0.1637 . It means that if current conditions remain unchanged, every $1 \%$ increase in environmental protection investment will bring a $16.37 \%$ increase in the two-periods lag return on total assets.

Table 5. The regression results of the impact of corporate environmental protection investment on corporate

\begin{tabular}{|c|c|c|c|}
\hline & Model (1a) & Model (1b) & Model (1c) \\
\hline Variable & $\mathbf{R O A}_{i, t}$ & $\mathbf{R O A}_{\mathrm{i}, \mathbf{t}}$ & $\mathbf{R O A}_{i, t}$ \\
\hline $\mathrm{EPI}_{\mathrm{i}, \mathrm{t}}$ & $\begin{array}{l}-0.3408^{*} \\
(-7.3281)\end{array}$ & & \\
\hline $\mathrm{EPI}_{\mathrm{i}, \mathrm{t}-1}$ & & $\begin{array}{c}0.0627 \\
(0.4103)\end{array}$ & \\
\hline$E P I_{i, t-2}$ & & & $\begin{array}{c}0.1637^{*} \\
(1.9925) \\
\end{array}$ \\
\hline Size $_{i, t}$ & $\begin{array}{c}0.0160 * * * \\
(3.8506) \\
\end{array}$ & $\begin{array}{c}0.0209 * * * \\
(4.1145) \\
\end{array}$ & $\begin{array}{c}0.0171 * * * \\
(3.9703)\end{array}$ \\
\hline $\operatorname{Lev}_{i, t}$ & $\begin{array}{c}-0.1764 * * * \\
(-5.5757) \\
\end{array}$ & $\begin{array}{c}-0.1927 * * * \\
(-5.8946) \\
\end{array}$ & $\begin{array}{c}-0.2689 * * * \\
(-6.3154)\end{array}$ \\
\hline $\mathrm{Liq}_{\mathrm{i}, \mathrm{t}}$ & $\begin{array}{c}-0.0072 \\
(-1.2513) \\
\end{array}$ & $\begin{array}{c}-0.0065 \\
(-1.1288) \\
\end{array}$ & $\begin{array}{c}-0.0099^{*} \\
(-0.9622) \\
\end{array}$ \\
\hline Equity $_{i, t}$ & $\begin{array}{c}0.0195 \\
(0.5762) \\
\end{array}$ & $\begin{array}{c}0.0184 \\
(0.5442) \\
\end{array}$ & $\begin{array}{c}0.0116 \\
(0.4329) \\
\end{array}$ \\
\hline $\operatorname{Pro}_{i, t}$ & $\begin{array}{c}-0.0455^{* * *} * \\
(-5.0124) \\
\end{array}$ & $\begin{array}{c}-0.0444 * * * \\
(-4.8992) \\
\end{array}$ & $\begin{array}{c}-0.0385 * * * \\
(-4.2330) \\
\end{array}$ \\
\hline $\operatorname{Age}_{i, t}$ & $\begin{array}{c}0.0342 * \\
(1.9295)\end{array}$ & $\begin{array}{l}0.0359 * * \\
(2.0235)\end{array}$ & $\begin{array}{c}0.0591 * \\
(2.4113) \\
\end{array}$ \\
\hline Constant & $\begin{array}{c}-0.0018 \\
(-0.0279) \\
\end{array}$ & $\begin{array}{c}-0.0215^{*} \\
(-1.8072)\end{array}$ & $\begin{array}{c}-0.0138^{*} \\
(-1.7516)\end{array}$ \\
\hline $\mathrm{N}$ & 1415 & 1132 & 849 \\
\hline F-statistic & $12.2403 * * *$ & $13.9227 * * *$ & $15.3134 * * *$ \\
\hline Adjusted $\mathrm{R}^{2}$ & 0.3706 & 0.3993 & 0.4382 \\
\hline
\end{tabular}

Note: $\mathrm{t}$ statistics are shown in brackets. $* * *, * *$ and $*$ respectively indicate that they pass the significance test at the levels of $1 \%, 5 \%$ and $10 \%$ (the same below). 
Integrating the regression results of model (1a) and (1b) and (1c), we can know that, as time goes by, the impact of environmental protection investment on corporate performance has a process from negative to positive. Although enterprises' environmental protection investment would have a negative impact on corporate performance in the short term, it will pay off for the corporate in the long run. Hypothesis 1 of this paper has been verified that the enterprises' environmental protection investment is negatively correlated with the short-term (oneyear) performance of enterprises, and is positively correlated with the corporate long-term (more than one year) performance. At the same time, it also indicates that enterprises shouldn't be short-sighted, because their investment in environmental protection will not bring immediate results for their performance, but insisting on environmental protection practices will ultimately improve corporate performance.

4.3.2 Test the Relationship between Technological Innovation and Corporate Performance

The impact of technology innovation on corporate performance and the lagging test regression results are shown in Table 6. The regression results of model (2a) show that the enterprises' R\&D intensity has no significant impact on the current return on total assets, it indicates that the enterprises' R\&D investment does not bring obvious economic benefits to enterprises in the short term. Model (2b) and model (2c) examine the impact of corporate R\&D intensity on the total return on assets lagging one and two phases, the regression results show that corporate R\&D intensity and the one-period lag return on total assets passed the significance test at the level of $10 \%$, the regression coefficient is 0.3065 . It shows that in the cases of existing conditions, every $1 \%$ increase in the R\&D investment will bring $30.65 \%$ increase to the one-period lag return on total assets of the corporate. Similarly, the R\&D intensity of enterprises is positively correlated with the two-periods lag return on total assets, the regression coefficient is $0.1982(\mathrm{P}<0.05)$, and the significance of $R \& D$ intensity on the return on total assets is enhanced. Based on the above results and analysis, hypothesis 2 of this paper is verified. It shows that technological innovation investment of enterprises has a positive influence on corporate performance, but the hysteresis exists in the influence.

Table 6 . The regression results of the impact of corporate technology innovation on corporate performance

\begin{tabular}{|c|c|c|c|}
\hline & Model (2a) & Model (2b) & Model (2c) \\
\hline Variable & $\mathbf{R O A}_{i, \mathbf{t}}$ & $\mathbf{R O A}_{i, t}$ & $\mathbf{R O A}_{\mathbf{i}, \mathbf{t}}$ \\
\hline $\mathrm{R} \& \mathrm{D}_{\mathrm{i}, \mathrm{t}}$ & $\begin{array}{c}0.2408 \\
(0.8526)\end{array}$ & & \\
\hline$R \& D_{i, t-1}$ & & $\begin{array}{c}0.3065^{*} \\
(3.1591)\end{array}$ & \\
\hline$R \& D_{i, t-2}$ & & & $\begin{array}{l}0.1982 * * \\
(3.6344)\end{array}$ \\
\hline Size $_{i, t}$ & $\begin{array}{c}0.0174 * * * \\
(4.1910)\end{array}$ & $\begin{array}{c}0.1048 * * \\
(2.372)\end{array}$ & $\begin{array}{c}0.0394 * * * \\
(4.6007)\end{array}$ \\
\hline $\operatorname{Lev}_{i, t}$ & $\begin{array}{c}-0.1688 * * * \\
(-5.2861)\end{array}$ & $\begin{array}{c}-0.2739 * * * \\
(-3.8336)\end{array}$ & $\begin{array}{c}-0.0143 * * * \\
(-2.5801)\end{array}$ \\
\hline $\mathrm{Liq}_{i, t}$ & $\begin{array}{l}-0.0064^{*} \\
(-3.1047)\end{array}$ & $\begin{array}{c}-0.0973 \\
(-0.3240)\end{array}$ & $\begin{array}{c}-0.1342 \\
(-0.8929)\end{array}$ \\
\hline Equity $_{i, t}$ & $\begin{array}{c}0.0216 \\
(0.6326)\end{array}$ & $\begin{array}{c}0.0099 \\
(0.1654)\end{array}$ & $\begin{array}{c}0.1075 \\
(0.5362)\end{array}$ \\
\hline Pro $_{i, t}$ & $\begin{array}{c}-0.0421 * * * \\
(-4.4405)\end{array}$ & $\begin{array}{c}-0.0837 * * * \\
(-4.8312)\end{array}$ & $\begin{array}{c}-0.0516^{* * *} \\
(-4.6792)\end{array}$ \\
\hline $\operatorname{Age}_{i, t}$ & $\begin{array}{l}0.0365 * * \\
(2.0552)\end{array}$ & $\begin{array}{c}0.0519 * \\
2.4181\end{array}$ & $\begin{array}{l}0.0018 * * \\
(3.0349)\end{array}$ \\
\hline Constant & $\begin{array}{l}-0.0328^{*} \\
(-3.4856)\end{array}$ & $\begin{array}{l}-0.0063^{*} \\
(-4.2194)\end{array}$ & $\begin{array}{c}0.0554 \\
(0.8306)\end{array}$ \\
\hline $\mathrm{N}$ & 1415 & 1132 & 849 \\
\hline F-statistic & $12.0180 * * *$ & $17.3049 * * *$ & $14.6973 * * *$ \\
\hline Adjusted $\mathrm{R}^{2}$ & 0.4383 & 0.4716 & 0.4021 \\
\hline
\end{tabular}

4.3.3 Test the Collaborative Impact of Environmental Protection Investment and Technological Innovation on Corporate Performance

Table 7 reports the regression results of the synergistic effect of environmental protection investment and technological innovation on corporate performance. In order to more clearly find the existence of the synergistic effect, our analysis is divided into two steps. The first step is to verify the synergistic effect of environmental protection investment and technological innovation on the short-term (one-year) performance on the basis of the model (1a) in Table 5 and the model (2a) in Table 6 by comparing with the model (3a) and the model (4a) in Table 7. The second step, based on the model (1c) in table 5 and the model (2c) in table 6 , we verify the synergistic effect 
of environmental protection investment and technological innovation on the long-term (more than one year) performance of enterprises by comparing with the model $(3 c),(4 c)$ in table $7^{1}$.

Table 7. The regression results of the synergistic impact of environmental protection investment and technological innovation on corporate performance

\begin{tabular}{|c|c|c|c|c|}
\hline & Model (3a) & Model（3c） & Model (4a) & Model (4c) \\
\hline Variable & $\mathbf{R O A}_{i, t}$ & $\mathbf{R O A}_{\mathbf{i}, \mathbf{t}}$ & $\mathbf{R O A}_{\mathbf{i}, \mathbf{t}}$ & $\mathbf{R O A}_{\mathbf{i}, \mathbf{t}}$ \\
\hline $\mathrm{EPI}_{\mathrm{i}, \mathrm{t}}$ & $\begin{array}{l}-0.1694^{*} \\
(-3.8129) \\
\end{array}$ & & $\begin{array}{l}-0.0750 * * \\
(-6.7608) \\
\end{array}$ & \\
\hline $\mathrm{EPI}_{\mathrm{i}, \mathrm{t}-2}$ & & $\begin{array}{l}0.2477 * * \\
(2.5496)\end{array}$ & & $\begin{array}{l}0.2602 * * \\
(1.5751)\end{array}$ \\
\hline$R \& D_{i, t}$ & $\begin{array}{c}0.2763 * \\
(3.3268)\end{array}$ & & $\begin{array}{c}0.2914 * \\
(3.8462) \\
\end{array}$ & \\
\hline $\mathrm{R} \& \mathrm{D}_{\mathrm{i}, \mathrm{t}-2}$ & & $\begin{array}{l}0.3745 * * \\
(4.9761)\end{array}$ & & $\begin{array}{l}0.3807 * * \\
(5.2192)\end{array}$ \\
\hline $\mathrm{EPI}_{\mathrm{i}, \mathrm{t}} * \mathrm{R} \& \mathrm{D}_{\mathrm{i}, \mathrm{t}}$ & & & $\begin{array}{l}26.5582 * \\
(1.6649) \\
\end{array}$ & \\
\hline $\mathrm{EPI}_{\mathrm{i}, \mathrm{t}-2} * \mathrm{R} \& \mathrm{D}_{\mathrm{i}, \mathrm{t}-2}$ & & & & $\begin{array}{l}33.9245^{*} \\
(1.7326)\end{array}$ \\
\hline Size $_{i, t}$ & $\begin{array}{c}0.0135 * * * \\
(3.9310)\end{array}$ & $\begin{array}{c}0.0102 * * * \\
(3.0760)\end{array}$ & $\begin{array}{c}0.0157 * * * \\
(3.7183)\end{array}$ & $\begin{array}{c}0.0253 * * * \\
(4.7787)\end{array}$ \\
\hline $\operatorname{Lev}_{\mathrm{i}, \mathrm{t}}$ & $\begin{array}{c}-0.2125^{* * * *} \\
(-3.3943) \\
\end{array}$ & $\begin{array}{c}-0.3829 * * * \\
(-7.0760) \\
\end{array}$ & $\begin{array}{c}-0.1755 * * * \\
(-5.5031) \\
\end{array}$ & $\begin{array}{c}-0.1890 * * * \\
(-5.6389) \\
\end{array}$ \\
\hline $\operatorname{Liq}_{i, t}$ & $\begin{array}{c}-0.0071 \\
(-1.2270) \\
\end{array}$ & $\begin{array}{c}-0.0458 \\
(-0.9112) \\
\end{array}$ & $\begin{array}{c}-0.0072 \\
(-0.1818) \\
\end{array}$ & $\begin{array}{c}-0.0034 \\
(-0.3186) \\
\end{array}$ \\
\hline Equity $_{\mathrm{i}, \mathrm{t}}$ & $\begin{array}{c}0.0227 \\
(0.6661)\end{array}$ & $\begin{array}{c}0.2900 \\
(1.4621)\end{array}$ & $\begin{array}{c}0.0197 \\
(0.5805)\end{array}$ & $\begin{array}{c}0.1038 \\
(1.4053)\end{array}$ \\
\hline Pro $_{i, t}$ & $\begin{array}{c}-0.0432 * * * \\
(-4.5497)\end{array}$ & $\begin{array}{c}-0.0685 * * * \\
(-4.9926)\end{array}$ & $\begin{array}{c}-0.0414 * * * \\
(-4.3477)\end{array}$ & $\begin{array}{c}-0.0542 * * * \\
(-4.8054)\end{array}$ \\
\hline $\mathrm{Age}_{\mathrm{i}, \mathrm{t}}$ & $\begin{array}{c}0.0349 * \\
(1.9615)\end{array}$ & $\begin{array}{c}0.0207^{*} \\
(1.5401) \\
\end{array}$ & $\begin{array}{c}0.0322 * \\
(1.8108) \\
\end{array}$ & $\begin{array}{l}0.0401 * * \\
(2.7234) \\
\end{array}$ \\
\hline Constant & $\begin{array}{c}-0.0192 \\
(-0.2349)\end{array}$ & $\begin{array}{c}0.0057 \\
(0.1318)\end{array}$ & $\begin{array}{c}0.0021 \\
(0.0812)\end{array}$ & $\begin{array}{c}-0.0119 \\
(-0.0702)\end{array}$ \\
\hline $\mathrm{N}$ & 1415 & 849 & 1415 & 849 \\
\hline F-statistic & $10.7876 * * *$ & 8.3615 & $9.9452 * * *$ & $13.3624 * * *$ \\
\hline Adjusted $\mathrm{R}^{2}$ & 0.4534 & 0.4283 & 0.4701 & 0.5009 \\
\hline
\end{tabular}

(1) The synergistic effect of environmental protection investment and technological innovation on long-term performance of enterprises. Based on the model (1c), comparing the model (1c), (3c) and model (4c), we can find the impact of environmental protection investment on the two-periods lag return on total assets is larger $(0.2477>0.1637)$ and the significance is increased from $10 \%$ to $5 \%$ after model (1c) join R\&D strength variables (get model (3c)). In addition, if the interaction term of environmental protection.

(2) The synergistic effect of environmental protection investment and technological innovation on short-term performance of enterprises. We simultaneously add environmental investment $\left(E P I_{i, t}\right)$ and $R \& D$ intensity $\left(R \& D_{i, t}\right)$ to construct Model (3a) on the basis of model (1a) and model (2a). The purpose is to investigate the influence of another variable on corporate performance by controlling one variable. After comparing model (1a), model (2a) and model (3a), we can find that in the case of controlling corporate investment protection environment, the impact of R\&D intensity on the total return on assets of the corporate has from not significant to significant $(\mathrm{P}<0.1)$, and its regression coefficient significantly larger $(0.2763>0.2408)$. It means that the regulatory effect of corporate environmental protection investment enhances the positive impact of R\&D intensity on corporate short-term performance. When the R\&D intensity is controlled, the negative impact of environmental protection investment on the current return on total assets of enterprises becomes smaller $(0.1694<0.3408, \mathrm{P}<0.1)$. It indicates that the regulating effect of $R \& D$ intensity weakens the negative impact of environmental protection investment on shortterm performance of enterprises.

\footnotetext{
${ }^{1}$ After inspection, environmental protection investment and technological innovation have a synergistic effect on the ROA lagging one or two phases. Considering that the two-periods lag ROA has a longer span, it can explain the long-term performance problem. Therefore, we use the two-periods lag ROA as the explanatory variable to illustrate the synergistic effect of environmental protection investment and technological innovation on long-term performance of enterprises.
} 
Model (4a) is an extended model based on model (3a) with the addition of interaction items $\left(\mathrm{EPI}_{\mathrm{i}, \mathrm{t}} * \mathrm{R}_{\mathrm{a}} \mathrm{D_{ \textrm {i } , \mathrm { t } }}\right)$ of environmental protection investment and R\&D intensity. By comparing the two models, we can find that after the addition of interaction term, not only the coefficient of interaction term is significant $(26.5582, \mathrm{P}<0.1)$, the goodness of fit of regression equation is improved $(0.4701>0.4534)$, but also the negative influence of environmental protection investment on the current return on total assets is further weakened $(0.0750<0.1694)$, and the significance level is increased from $10 \%$ to $5 \%$. And R\&D intensity of enterprises still has a significant impact on the current return on total assets $(0.2914, \mathrm{P}<0.1)$. Based on the above analysis, we can conclude that enterprises can weaken the negative impact of environmental protection investment on short-term performance through technological innovation, and promote the positive impact of technological innovation on short-term performance through environmental protection investment practice. That is to say, environmental protection investment and technological innovation regulate each other and have a synergistic effect on the short-term performance of enterprises.

(3) Investment and R\&D intensity is added into the model (get model (4c)), not only the coefficient of the interaction term is significant $(33.9245, \mathrm{P}<0.1)$, but also the positive influence of environmental protection investment on the two-periods lag return on total assets is further increased $(0.2602>0.2477)$. It indicates that the investment of enterprises technology innovation has a strong moderating effect on the relationship between environmental protection investment and long-term performance of enterprises.

Similarly, on the basis of model (2c), comparing the model (2c), (3c) and model (4c), we find that the regression coefficient between R\&D intensity and the two-periods lag return on total assets becomes larger $(0.3745>0.1982)$ after model (2c) joining environmental protection investment variable (get model (3c)). It shows that the influence of technological innovation on corporate long-term performance is increased under the control of environmental protection investment variables. In addition, if the interaction term of environmental protection investment and R\&D intensity is added into the model (get model (4c)), the impact of corporate R\&D intensity on the two-periods lag return on total assets is still significant, the regression coefficient is $0.3807(\mathrm{P}<0.05)$, and the interaction coefficient is also significant. It indicates that environmental protection investment has a moderating effect on the relationship between technological innovation and long-term performance of enterprises. The above results show that environmental protection investment and technological innovation of enterprises can adjust each other and jointly affect the long-term performance of enterprises.

Based on the detailed analysis of the first and second steps, we can conclude that the influence of environmental protection investment and technological innovation on the short-term and long-term performance of enterprises can form a synergistic effect of "1+1>2", the existence of which also can make the corporate pay attention to environmental protection investment and increasing the financial input in technology innovation, thus the environmental protection investment, technology innovation and corporate performance form a virtuous circle. Therefore, the hypothesis 3 is verified, namely, environmental protection investment and technological innovation regulate each other and play a synergistic effect on corporate performance.

\subsection{Robustness Test}

In this paper, the method of variation replacement is used to test the robustness of the research results. In order to rule out the deviations that measurements of key variables may bring to the research results, we take return on equity (ROE) instead of return on total assets (ROA) to measure corporate performance, and R\&DTS instead of R\&D intensity to measure corporate investment in technological innovation (Zhang \& Wu 2014). The robustness test results (limited by space and not listed) further support the above research conclusions. It indicates that our empirical research results are not affected by the variable measurement, and the research conclusions are robust and reliable.

\section{Conclusions}

\subsection{Research Conclusions}

Taking listed companies in China's heavy pollution industries as research objects, we reveal the complex relationship between environmental protection investment, technological innovation and corporate performance from short-term and long-term perspectives, especially the synergistic effect of environmental protection investment and technological innovation on corporate performance. The results show that: (1) the environmental protection investment has a significant negative impact on the short-term (within a year) performance of the corporate, and it has no significant impact on the one-period lag corporate performance, but it has a significant positive impact on the two-periods lag corporate performance. It shows that the influence of environmental protection investment on corporate performance changes from negative to positive over time; (2) the investment in technological innovation has a positive impact on corporate performance, but the hysteresis exists in the impact; and (3) environmental protection investment and technological innovation investment of enterprises regulate each other, and play a positive role in short-term (within one year) and long-term (over one year) performance of enterprises. In other words, it can form a synergistic effect of " $1+1>2$ " that the influence of environmental 
protection investment and technological innovation on the short-term and long-term performance of enterprises.

\subsection{Policy Recommendations}

The performance of a company is not only dependent on its ability to acquire, dispatch and comprehensively utilize its own resources, but also related to the external environment such as national policies, social supervision and support. Therefore, the research conclusions drawn from the empirical analysis in this paper have important implications for enterprises, the government and the public.

(1) The company shall establish a strategy integrating environmental protection and technological innovation. Corporate environmental protection investment and technological innovation have a synergistic effect on corporate performance. For enterprises, environmental investment and technological innovation should be integrated into an overall strategic decision. That is to say, the enterprises should establish a global environmental strategy and technology innovation strategy, namely, enterprises need to increase the technology innovation investment in environmental management to meet customer demand and maintain the market competition advantages. Correspondingly, in order to obtain the affirmation and support of stakeholders, enterprises need to actively fulfill their environmental responsibilities and increase investment in environmental protection while increasing their innovation capabilities. Thus enterprises should pay full attention to and make use of the synergistic effect to make the effect of $" 1+1>2$ " on environmental protection investment and technological innovation.

(2) Government departments should strengthen environmental violation supervision and increase subsidies for environmental protection and research and development. In addition, relevant departments should strive to realize the modernization and intelligence of environmental governance, strengthen environmental violation supervision, raise the cost of environmental violations, formulate relevant policies to encourage enterprises to actively fulfill their environmental responsibilities, and guide enterprises to actively increase investment in environmental protection. At the same time, they need to strengthen the protection of intellectual property rights, improve the incentive mechanism for corporate environmental protection and research and development, and appropriately increase financial subsidies.

(3) On the one hand, the public should take the initiative to improve the awareness of environmental protection, practice the concept of green environmental protection, and support the development of green enterprises. For example, consumers buy more products of green enterprises, investors take an active part in direct financing of green enterprises, and supply chain partners mostly cooperate with green companies and so on. On the other hand, we should actively play the main role of public opinion supervision, dare to expose environmental violations to environmental authorities, and form public opinion pressure on enterprises that violate environmental laws and regulations. Only in this way, can enterprises increase their investment in environmental protection effectively, and force enterprises to carry out technological innovation to accelerate the upgrading and transformation of backward production mode, so as to achieve the harmonious development of man and nature.

\section{References}

Wang, P., Xie, L.W. (2014). "Pollution Control Investment, corporate Technical Innovation and Pollution Control Efficiency", China Population, Resources and Environment 24(9), 51-58. (in Chinese).

Lopez-Gamero, M.D., Molina-Azorin, J.F., Claver-Cortes, E. (2010), "The potential of environmental regulation to change managerial perception, environmental management, competitiveness and financial performance", Journal of Cleaner Production 18(10), 963-974.

Broberg, T., Marklund, P.O., Samakovlis, E. (2013), "Testing the Porter hypothesis: the effects of environmental investments on efficiency in Swedish industry", Journal of Productivity Analysis 40(1), 43-56.

Walley, N., Whitehead, B. (1994), "It's not easy being green”, Harvard Business Review 72(3), 46-52.

Sarkis, J., Gonzalez-Torre, P., Adenso-Diaz, B. (2010), "Stakeholder pressure and the adoption of environmental practices: The mediating effect of training", Journal of Operations Management 28(2), 163-176.

Russo, M.V., Fouts, P.A. (1997), "A Resource-Based Perspective on Corporate Environmental Performance and Profitability”, Academy of Management Journal 40(3), 534-559.

Sharfman, M.P., Fernando, C.S. (2008), "Environmental risk management and the cost of capital", Social Science Electronic Publishing 29(6), 569-592.

Rob, G., Jan, B. (2009), “Accounting for the Environment”, London: Sage Pubns 16(6), 65-83.

Zhao Yating. (2015), "Industry Attributes, Corporate Environmental Expenditure and Financial Performance", Friends of Accounting (7), 73-77. (in Chinese).

Liu, Z.W., Duan S.S. (2013), "U-shaped Relationship Between Company Environmental Performance and Financial Performance_-An Empirical Research Based on the Manufacturing Industry Listed Companies in China", East China Economic Management (11), 111-115. (in Chinese).

Tsai, K.H., Wang, J.C. (2010), "R\&D Productivity and the Spillover Effects of High-tech Industry on the Traditional Manufacturing Sector: The Case of Taiwan", World Economy 27(10), 1555-1570.

Liang, L.X., Zhang H.F. (2005), “An empirical study on the R\&D inputs performance of high-tech enterprises”, 
Journal of Central South University(Social Science) 11(2), 232-236. (in Chinese).

Zhang, B.T. (2008), "An empirical study on acceleration trap in patent R\&D: The evidence from Chinese Listed mechanical manufacturing companies”, Science Research Management 29(3), 89-97. (in Chinese).

Wu, X.Y., Chen, Y., Li, X.L., Li, Z.K. (2017), "R\&D investment, government subsidies and corporate value of strategic emerging industries", Science Research Management 38(9), 30-34. (in Chinese).

Chan, L.K.C., Lakonishok, J., Sougiannis, T. (2001), "The Stock Market Valuation of Research and Development Expenditures", The Journal of Finance 56(6), 2431-2456.

Luo, T., Zhu, Q., Li, D. (2009), “Analysis of the Relationship between R\&D Investment and Corporate Value”, Journal of Financial Research (6), 100-110. (in Chinese).

Chen, S., Shi X.B., Wu S.Y. (2015), "Impact of Complementary Asset Synergy on Performance_-Form the Prospect of Moderating Effect of Environmental Dynamism”, Systems Engineering (1), 61-67. (in Chinese).

Zhu, N.P., Zhu, L., Kong, Y.S., Shen, Y. (2014), "Study on Interaction of Technological Innovation Investment and Corporate Social Responsibility on Corporate Financial Performance", Accounting Research (2), 57-63. (in Chinese).

Lioui, A., Sharma, Z. (2012), "Environmental corporate social responsibility and financial performance: Disentangling direct and indirect effects", Ecological Economics 78(32), 100-111.

Horváthová, E. (2011), "Does environmental performance affect financial performance? A meta-analysis", Ecological Economics 70(1), 52-59.

Tang, G.P., Li L.H., Wu D.J. (2013), “Environmental Regulation, Industry Attributes and corporate Environmental Protection Investment", Accounting Research (6), 83-89. (in Chinese).

Wang, P., Zhang, J. (2016), "Ownership Structure, Corporate Environmental Investment and Financial Performance", Journal of Wuhan University of Technology(Information \& Management Engineering) 38(6), 735-739. (in Chinese).

Zhang X.D., Wu J.J. (2014), "Government R\&D Funding Strength, corporate R\&D Capability and Innovation Performance_-Based on Empirical Evidence of GEM Listed Companies”, Science \& Technology Progress and Policy (22), 7-13. (in Chinese).

Yang, N. (2015), "Capital Structure, Technological Innovation and Firm Performance_—Based on the Empirical Analysis of Listed Companies in China", Social Sciences of Beijing (7), 113-120. (in Chinese).

Wu, C.P., Tang, W. (2016), "Intellectual Property Rights Enforcement, Corporate Innovation and Operating Performance: Evidence from China's Listed Companies", Economic Research Journal (11), 125-139. (in Chinese).

Liu, Z.W., Duan S.S. (2013), "U-shaped Relationship Between Company Environmental Performance and Financial Performance-An Empirical Research Based on the Manufacturing Industry Listed Companies in China", East China Economic Management (11), 111-115. (in Chinese). 